\title{
Kindling Enhances Sensitivity of CA3 Hippocampal Pyramidal Cells to NMDA
}

\author{
David Martin, ${ }^{1}$ James O. McNamara, ${ }^{1,2,3}$ and J. Victor Nadler ${ }^{1,2}$ \\ Departments of 'Pharmacology, ${ }^{2}$ Neurobiology, and ${ }^{3}$ Medicine (Neurology), Duke University Medical Center, Durham, \\ North Carolina 27710
}

Kindling is a form of experimental epileptogenesis in which periodic electrical stimulation of a brain pathway induces a permanently hyperexcitable state. Previous studies suggested that kindling might be explained, at least in part, by an increased sensitivity of brain neurons to NMDA receptor agonists. This possibility was investigated with the use of grease-gap preparations for assaying the depolarizing responses of CA3 and CA1 hippocampal pyramidal cells to amino acid excitants. When studied 1-2 months after the last evoked seizure, CA3 pyramidal cells from kindled rats were five- to sixfold more sensitive to NMDA than CA3 pyramidal cells from controls. A similar, though smaller, effect of stimulation was observed $1 \mathrm{~d}$ after the last evoked seizure. The greater potency of NMDA in kindled rats can probably be explained by enhanced expression of NMDA receptors in the presence of a receptor reserve. The stimulation protocol did not alter the ability of $\mathbf{M g}^{2+}$ to reduce NMDA potency. It also affected neither the response of CA3 pyramidal cells to AMPA [(RS)- $\alpha$-amino-3-hydroxy-5-methyl-4isoxazolepropionate] nor the response of CA1 pyramidal cells to NMDA or AMPA. In area CA3, the potency of NMDA, but not of AMPA, declined 2.5-4-fold over the 1-2 month experimental period, apparently as a result of increasing age. This age-related loss of sensitivity to NMDA was completely prevented by kindling.

These findings suggest that kindling prevents a loss of NMDA receptor function in CA3 pyramidal cells that normally occurs during early adulthood. Such a change could contribute to maintenance of the kindled state.

Several forms of long-lasting neuronal plasticity depend on activation of the NMDA type of excitatory amino acid receptor. These include such diverse phenomena as activity-dependent modification of neuronal response properties in the developing visual cortex (Kleinschmidt et al., 1987; Gu et al., 1989; Bear et al., 1990), the stabilization and disconnection of synapses during the development of the brain (Cline and ConstantinePaton, 1989; Artola et al., 1990), long-term potentiation (Collingridge et al., 1983), and even tolerance to and dependence upon opiates (Marek et al., 1991; Trujillo and Akil, 1991). Al-

Received Aug. 2, 1991; revised Dec. 26, 1991; accepted Dec. 27, 1991.

We thank Ms. L. Butler for stimulating the animals and Ms. K. Gorham for secretarial assistance. This study was supported by NIH Grants NS 17771 and NS 16064.

Correspondence should be addressed to J. Victor Nadler, Department of Pharmacology, Box 3813, Duke University Medical Center, Durham, NC. 27710.

Copyright (c) 1992 Society for Neuroscience $0270-6474 / 92 / 121928-08 \$ 05.00 / 0$ though activation of the NMDA receptor is crucial for the induction of long-lasting plasticity, it appears to be of lesser importance for the expression or maintenance of the change. Kindling may be an exception to this generalization.

Kindling is an animal model of epilepsy and neuronal plasticity in which periodic administration of an initially subconvulsive electrical stimulus eventually results in a generalized electrographic and behavioral seizure (Goddard et al., 1969). Once developed, this enhanced sensitivity to electrical stimulation seems to endure for the life of the animal. Cellular mechanisms that underlie the establishment and maintenance of the kindled state have been suggested to play a role in human epilepsy (McNamara et al., 1985), although these mechanisms are poorly understood. As expected for a robust, long-lasting form of neuronal plasticity, kindling develops only when the electrical stimuli activate the NMDA receptor. NMDA receptor antagonists potently suppress development of the kindled state (Callaghan and Schwark, 1980; Croucher et al., 1988; McNamara et al., 1988; Holmes et al., 1990) but attenuate kindled seizures only at higher doses (Callaghan and Schwark, 1980; Peterson et al., 1983; McNamara et al., 1988; Löscher and Hönack, 1991). These results could be interpreted to suggest that the NMDA receptor is crucial for development of this form of plasticity but plays a lesser role in its expression. However, they might also be explained by enhancement of NMDA receptor function during the kindling process. In support of the latter idea, electrophysiological studies demonstrated that NMDA receptors on dentate granule cells are more readily activated in hippocampal slices from kindled rats than in slices from control rats (Mody and Heinemann, 1987; Mody et al., 1988). Kindling could produce this change by several different mechanisms, which may, but need not, involve a selcctive modification of NMDA receptor expression or regulation.

A study of carbachol-stimulated phosphatidyl inositol (PI) turnover provided evidence for a selective enhancement of NMDA agonist potency during the kindling process (Morrisett et al., 1989). NMDA more potently depressed carbachol-stimulated PI turnover in hippocampal slices from kindled rats than in slices from control rats. This action of NMDA has been shown to depend on neuronal depolarization rather than on $\mathrm{Ca}^{2+}$ influx through the receptor channel (Baudry et al., 1986; Morrisett et al., 1990). Kindling appeared to enhance responses to NMDA selectively, because it affected neither basal nor carbachol-stimulated PI turnover and did not alter the depressant effects of kainate or phorbol ester upon the carbachol-induced stimulation. These results suggested that, after kindling, NMDA more potently depolarized hippocampal neurons. However, this in- 
direct measure of depolarization proved inadequate to determine which neuronal populations were affected and to explore the mechanism involved. We therefore turned to grease-gap preparations of the hippocampus that permit the determination of pharmacological parameters for specific neuronal types (Martin et al., 1989; Martin and Nadler, 1991). This goal can be achieved while maintaining the target cells in a near-normal environment. The quantitative pharmacology of amino acid receptors in systems of this type has proved sufficiently reproducible to permit comparisons across groups of animals subjected to different pretreatments (e.g., Lindgren and Simmonds, 1987; Bowe and Nadler, 1990).

Brief accounts of this work have appeared previously (Martin et al., 1990; Nadler et al., 1990).

\section{Materials and Methods}

Kindling. Male Sprague-Dawley rats were purchased from Charles River Laboratories (Wilmington, NC) at the age of 80-90 d. Animals were implanted with electrodes in the angular bundle (entorhinohippocampal fibers) and electrically stimulated twice daily as described by Okazaki et al. (1989). Stimulation continued until the animal had responded to at least six stimulus trains with a class 4-5 limbic motor seizure (Racine, 1972), the last three such responses being consecutive. Subjects were then set aside for either $1 \mathrm{~d}$ or 1-2 months, during which time no additional stimulation was administered. On the day of death, rats in the $1 \mathrm{~d}$ group were about 4 months old and rats in the 1-2 month group were $5.5-6$ months old.

Two control groups were studied. One group ("controls") consisted of rats that were implanted with electrodes at the same time as the kindled animals but were not electrically stimulated. Kindled rats and implanted controls were studied on alternate days. The second control group ("unoperated") consisted of rats that were purchased at the same age as the kindled rats and implanted controls and that were maintained in our vivarium facility for the same length of time, but never underwent electrode implantation. Only the responses to excitants of CA3 pyramidal cells were studied in unoperated animals.

Grease-gap preparation. Experiments were performed without knowledge of whether the animal had been stimulated. At the appropriate survival time, the rat was anesthetized with ether and decapitated. CA1subiculum or CA3-CAl slices were prepared from $450-\mu \mathrm{m}$-thick slices of the hippocampal formation as described in detail elsewhere (Martin et al., 1989; Martin and Nadler, 1991). Each slice was transferred to a two-compartment superfusion chamber, and a grease barrier was formed at the CA1-subiculum or CA3-CA2 border, such that the CA1 pyramidal cell bodies and dendrites in the first case or CA3 pyramidal cell bodies and dendrites in the second case lay in one compartment and their axons projected through the grease barrier into the other compartment. The compartments were independently superfused at $2 \mathrm{ml}$ / min with artificial cerebrospinal fluid of the following composition (in mmol/liter): $\mathrm{NaCl}, 122 ; \mathrm{NaHCO}_{3}, 25 ; \mathrm{KCl}, 3.1 ; \mathrm{KH}_{2} \mathrm{PO}_{4}, 0.4 ; \mathrm{CaCl}_{2}$, 1.3; $\mathrm{MgSO}_{4}, 1.0$; D-glucose, $10, \mathrm{pH}$ 7.4. The medium was bubbled continuously with $95 \% \mathrm{O}_{2} / 5 \% \mathrm{CO}_{2}$, and the temperature of the tissue compartments was maintained at $32^{\circ} \mathrm{C}$. When excitants were tested in the absence of added $\mathrm{Mg}^{2+}, \mathrm{Mg}^{2+}$ was removed from the medium $1 \mathrm{hr}$ after the start of superfusion.

Pharmacological testing. The protocols used have been published previously (Martin et al., 1989; Bowe and Nadler, 1990; Martin and Nadler, 1991). Briefly, amino acid excitants were tested by replacing the medium superfusing the test compartment (CA1 or $\mathrm{CA} 3$ ) for 2 min with 5.7 compartment volumes $(4 \mathrm{ml})$ of medium that contained the excitant. Two minutes of superfusion were sufficient to evoke a full response. Only one excitant was tested on each slice. Concentrationresponse curves were generated by applying a set of excitant concentrations in random order. At least $10 \mathrm{~min}$ were allowed for recovery between applications of the excitant. In most experiments, a concentration-response curve was obtained in the absence and then in the presence of added $\mathrm{Mg}^{2+}$. However, a few slices were tested only in the absence or only in the presence of $\mathrm{Mg}^{2+}$.

Effects of excitatory amino acids on membrane potential were determined from the deflection in the DC potential differentially recorded between the two compartments. The DC potential difference is proportional to the current flow evoked by exposure of cells to the amino acid (Williams et al., 1988; Simmonds, 1990; Martin and Nadler, 1991). Because pyramidal cells are by far the predominant neuronal type in area $\mathrm{CA} 3$ and few, if any, other neurons in this region project to area $C A 1$, responses recorded in this study were assumed to represent depolarizations of CA3 pyramidal cells. Similar considerations led us to regard responses recorded from $\mathrm{CA} 1$-subiculum slices as representations of CA1 pyramidal cell depolarization. Electrotonically coupled glial cells can form an alternative pathway for current flow through the grease barrier (Simmonds, 1990). Thus, a portion of the response to excitant could have arisen from depolarization of glia as a result of $\mathrm{K}^{+}$ efflux from neurons. However, this component, if present, indirectly reflected the depolarization of pyramidal cells and did not represent a separate action of the excitants. $(R S)$ - $\alpha$-amino-3-hydroxy-5-methyl-4isoxazolepropionate (AMPA) and glutamate, but apparently not NMDA, can also depolarize astrocytes through a direct receptor-mediated action (Usowicz et al., 1989; Glaum et al., 1990). The direct depolarization of astrocytes appears to contribute little toward the recorded responses, however, at least in area $\mathrm{CA} 1$, because superfusing the retrohippocampal compartment of CA1-subiculum slices with AMPA failed to elicit a measurable depolarization (Martin et al., 1989). Depolarization of electrotonically coupled glia should be recorded equally well from both sides of the grease barrier.

Because high concentrations of excitatory amino acids irreversibly attenuate responses to all excitants in these preparations, the highest concentrations used were those that evoked just-maximal depolarizations. The maximal concentrations of NMDA (Tocris Neuramin, Essex, UK) chosen for testing in the absence of added $\mathrm{Mg}^{2+}$ were as follows: CA3 $1 \mathrm{~d}$ control and unoperated groups, 40-80 $\mu \mathrm{M}$; CA3 1-2 month control and unoperated groups, $120-320 \mu \mathrm{M} ; \mathrm{CA} 31 \mathrm{~d}$ and $1-2$ month

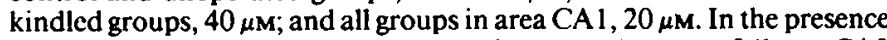
of $1 \mathrm{mM} \mathrm{Mg}^{2+}$, the maximal concentrations tested were as follows: $\mathrm{CA} 3$

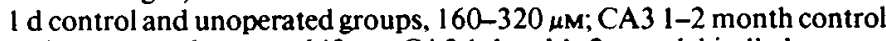
and unoperated groups, $640 \mu \mathrm{M} ; \mathrm{CA} 3 \mathrm{I}$ d and $\mathrm{I}-2$ month kindled groups, $80 \mu \mathrm{M}$; and all groups in area CAl, $40 \mu \mathrm{M}$. The just-maximal concentration of AMPA (Research Biochemicals, Natick, MA) for kindled and control groups in both hippocampal regions was $20 \mu \mathrm{M}$, and for L-glutamate in area CA3 it was $8 \mathrm{~mm}$, whether or not $\mathrm{Mg}^{2+}$ was added to the medium. As long as agonist concentrations higher than these were avoided, we found no evidence of hysteresis.

Data analysis. Each response was amplified, recorded on chart paper, and measured in millivolts from onset to peak. $\mathrm{EC}_{30}$ values were estimated by a least-squares regression of the linear portion of semilogarithmic concentration-response curves (Tallarida and Murray, 1987). Because $\mathrm{EC}_{50}$ values are not normally distributed, all statistical analyses were performed on the $\log _{10}$ transformations of these values $\left(\mathrm{pEC}_{30}\right)$ (Gaddum, 1945; Fleming et al., 1972). The absolute magnitude of excitant-induced depolarizations varied with the preparation and with the resistance of the grease seal. For graphical presentation, therefore, all responses were normalized to the maximal response obtained in the same slice. Differences among slices in absolute response amplitude had no obvious effect upon the calculated $\mathrm{EC}_{\mathrm{s0}}$ values.

\section{Results}

Area CA3. Kindling enhanced the sensitivity of the CA3 pyramidal cell population to NMDA, when compared to implanted controls (Figs. 1, 2). Similar enhancements were observed in the absence and presence of added $\mathrm{Mg}^{2+}$. A three-way ANOVA (treatment $\times$ time $\times \mathrm{Mg}^{2+}$ ) performed on the $\mathrm{pEC}_{50}$ values (Table 1) yiclded significant effects of all three variables $(p<$ 0.01 ). The effect of kindling increased significantly with time after the last evoked scizure $(p<0.01)$. However, neither kindling nor time after the last evoked seizure altered the ability of $1 \mathrm{mM} \mathrm{Mg}^{2+}$ to reduce NMDA potency $(p>0.1)$. Breakdown of the ANOVA followed by a Newman-Keuls test confirmed the greater sensitivity of CA3 pyramidal cells to NMDA in slices from kindled rats, although $1 \mathrm{~d}$ after the last evoked seizure this effect achieved statistical significance only in the presence of added $\mathrm{Mg}^{2+}$ (Table 1). In the absence of added $\mathrm{Mg}^{2+}$, the $\mathrm{EC}_{\text {so }}$ for NMDA was $71 \%$ of the control value $1 \mathrm{~d}$ after the last evoked seizure, but only $17 \%$ of the control value $1-2$ months after the last evoked seizure. 
Figure 1. Depolarization of CA3 hippocampal pyramidal cells evoked by various concentrations of NMDA in slices from kindled (bottom) and control $(t o p)$ rats studied 1-2 months after the last evoked seizure. Traces represent the DC potential differentially recorded between the pyramidal cell bodies and dendrites in area CA3 and their axons in area CA1 (Martin et al., 1989). The voltage deflections produced by each concentration of NMDA were taken as a measure of neuronal depolarization. Extracellular negativity is upward. Note higher NMDA potency in slices from the kindled rat and that, when $\mathbf{M g}^{2+}$ was added to the superfusion medium, NMDA concentrations had to be increased by about the same percentage in slices from control and kindled animals to evoke responses of the same amplitude. Also note the lack of afterhyperpolarization in slices from control rat.

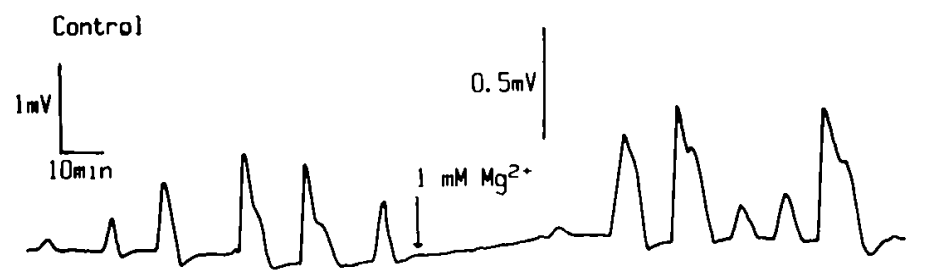

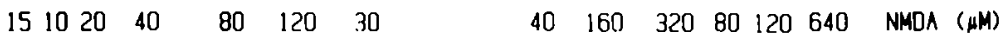

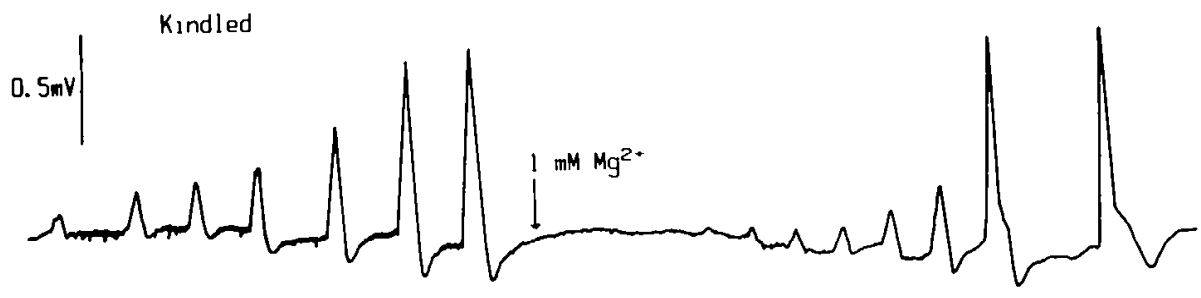

$\begin{array}{lllllllllllllllll}5 & 7.5 & 10 & 15 & 20 & 30 & 40 & & 10 & 15 & 20 & 25 & 30 & 40 & 80 & 160 & \text { NMDA ( } M M)\end{array}$
This effect of kindling was supcrimposed upon a time-dependent reduction of NMDA potency in the controls (Fig. 2, Table 1). The $E C_{50}$ in area $\mathrm{CA} 3$ increased by $2.5-4$-fold during the $1-$ 2 month period (Table 1). In contrast, the $\mathrm{EC}_{50}$ for NMDA remained constant in slices from kindled rats during the same period. CA3-CA 1 slices from age-matched (4 and 5.5-6 months), but unoperated, rats were studied to determine whether the loss of NMDA potency in the implanted controls was caused by implantation of the stimulating electrode or by normal development. Results obtained from these animals closely resembled those obtained from implanted controls, suggesting that a loss of NMDA potency may be associated with the normal development of CA3 pyramidal cells in young adult male rats. Kindling abolished this developmental change.

Studies of unoperated animals younger and older than those used in the kindling study supported the idea that CA3 pyramidal cells lose sensitivity to NMDA with advancing age. In slices from 1.5-month-old rats, NMDA was about as potent a depolarizing agent as in slices from 4-month-old rats $\left[0 \mathrm{Mg}^{2+}\right.$ : $\mathrm{EC}_{50}, 14 \mu \mathrm{M} ; \mathrm{pEC}_{50}, 4.86 \pm 0.06($ mean $\pm \mathrm{SEM} ; n=6) ; 1 \mathrm{mM}$ $\mathrm{Mg}^{2+}: \mathrm{EC}_{50}, 32 \mu \mathrm{M} ; \mathrm{pEC}_{50}, 4.49 \pm 0.05$ (mean $\pm \mathrm{SEM} ; n=5$ ); cf. Table 1]. NMDA was much less potent at 10-12 months of age $\left[0 \mathrm{Mg}^{2}\right.$ : $\mathrm{EC}_{50}, 46 \mu \mathrm{M} ; \mathrm{pEC}_{50}, 4.34 \pm 0.04$ (mean $\pm \mathrm{SEM}$; $n=6)]$.

The normal development of CA3 pyramidal cells altered responses to NMDA in another respect. It markedly diminished the afterhyperpolarization. In slices from 4-month-old control rats, a 2-min application of NMDA produced a rapid depolarization followed by a slow hyperpolarization. In slices from the older control and unoperated rats, however, the duration of the
Figure 2. NMDA concentration-response relationships in area $\mathrm{CA} 3$ of slices from kindled rats $(\bullet)$ tested either $1 \mathrm{~d}$ or $1-2$ months after the last evoked seizure, from control rats $(O)$ tested at the same time after electrode implantation alone, and from unimplanted rats $(\Delta)$ of the same age tested after an equivalent stay in the same animal facility. Values are means \pm SEM for the number of animals given in Table 1 . NMDA potency was greater in slices from kindled rats and the concentration-response curves shifted to the right in older animals.

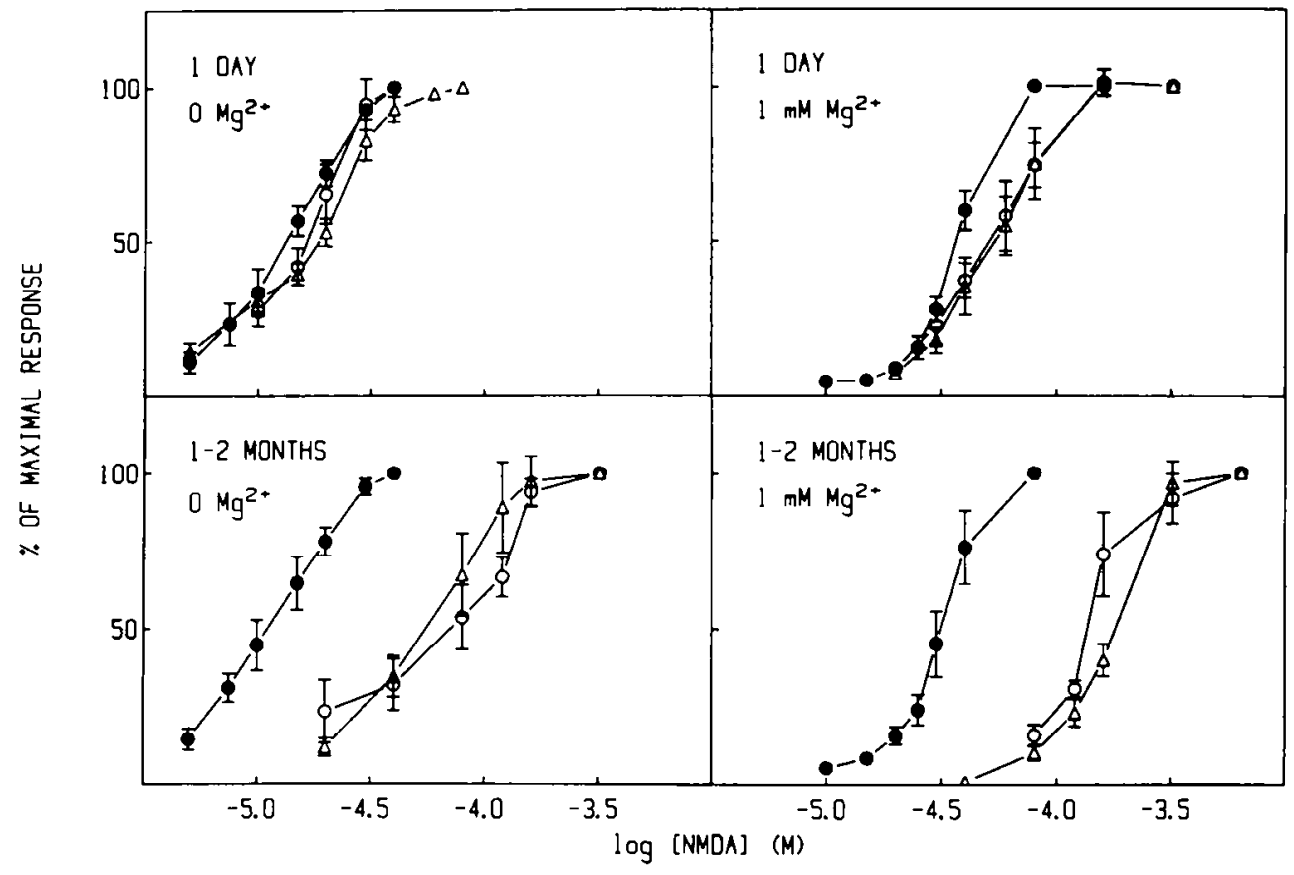




\begin{tabular}{|c|c|c|c|c|c|}
\hline Excitant/region & Time & $\begin{array}{l}{\left[\mathrm{Mg}^{2+}\right]} \\
(\mathrm{mM})\end{array}$ & Unoperated & Control & Kindled \\
\hline \multirow[t]{4}{*}{ NMDA/CA3 } & $1 \mathrm{~d}$ & 0 & $\begin{array}{l}4.75 \pm 0.04(8) \\
18\end{array}$ & $\begin{array}{l}4.77 \pm 0.05(8) \\
17\end{array}$ & $\begin{array}{l}4.90 \pm 0.05(6) \\
13\end{array}$ \\
\hline & & 1 & $\begin{array}{l}4.23 \pm 0.05(8) \\
59\end{array}$ & $\begin{array}{l}4.28 \pm 0.04(8) \\
\quad 52\end{array}$ & $\begin{array}{l}4.43 \pm 0.03(8)^{*} \\
\quad 37\end{array}$ \\
\hline & 1-2 mo & 0 & $\begin{array}{c}4.18 \pm 0.09(5) \\
66\end{array}$ & $\begin{array}{l}4.15 \pm 0.08(9) \\
\quad 71\end{array}$ & $\begin{array}{l}4.94 \pm 0.05(7)^{* *} \\
\quad 12\end{array}$ \\
\hline & & 1 & $\begin{array}{l}3.70 \pm 0.06(4) \\
200\end{array}$ & $\begin{array}{l}3.82 \pm 0.04(6) \\
151\end{array}$ & $\begin{array}{l}4.46 \pm 0.04(8)^{* *} \\
\quad 35\end{array}$ \\
\hline NMDA/CAl & $1-2 \mathrm{mo}$ & 0 & & $\begin{array}{l}5.24 \pm 0.05(5) \\
5.8 \\
4.80 \pm 0.02(9) \\
16\end{array}$ & $\begin{array}{l}5.27 \pm 0.04(6) \\
5.4 \\
4.75 \pm 0.01(8) \\
18\end{array}$ \\
\hline \multirow[t]{2}{*}{ AMPA/CA3 } & $1 \mathrm{~d}$ & 1 & & $\begin{array}{l}5.53 \pm 0.07(7) \\
3.0 \\
5.41 \pm 0.09(8) \\
3.9\end{array}$ & $\begin{array}{l}5.36 \pm 0.04(6) \\
4.4 \\
5.30 \pm 0.08(10) \\
5.0\end{array}$ \\
\hline & 1-2 mo & 0 & & $\begin{array}{l}5.30 \pm 0.12(6) \\
5.0 \\
5.23 \pm 0.07(7) \\
5.9\end{array}$ & $\begin{array}{l}5.46 \pm 0.08(7) \\
3.5 \\
5.36 \pm 0.07(7) \\
4.4\end{array}$ \\
\hline AMPA/CAl & $1-2 \mathrm{mo}$ & 0 & & $\begin{array}{l}5.64 \pm 0.10(6) \\
2.3 \\
5.54 \pm 0.08(6) \\
2.9\end{array}$ & $\begin{array}{l}5.49 \pm 0.10(6) \\
3.2 \\
5.38 \pm 0.08(6) \\
4.2\end{array}$ \\
\hline \multirow[t]{4}{*}{ L-Glutamate/CA3 } & $1 \mathrm{~d}$ & 0 & & $\begin{array}{l}2.72 \pm 0.06(6) \\
1900\end{array}$ & $\begin{array}{l}2.78 \pm 0.01(6) \\
1700\end{array}$ \\
\hline & & 1 & & $\begin{array}{l}2.73 \pm 0.03(8) \\
1900\end{array}$ & $\begin{array}{l}2.79 \pm 0.02(9) \\
1600\end{array}$ \\
\hline & 1-2 mo & 0 & & $\begin{array}{l}2.88 \pm 0.04(10) \\
1300\end{array}$ & $\begin{array}{l}2.81 \pm 0.06(7) \\
1600\end{array}$ \\
\hline & & 1 & & $\begin{array}{l}2.77 \pm 0.03(10) \\
1700\end{array}$ & $\begin{array}{l}2.79 \pm 0.06(7) \\
1600\end{array}$ \\
\hline
\end{tabular}

$\mathrm{pEC}_{s 0}$ is $-\log \left[\mathrm{EC}_{30}\right] \cdot \mathrm{pEC}_{s_{0}}$ values are means $\pm \mathrm{SEM}$ for the number of preparations given in parentheses. $\mathrm{EC}_{50}$ values $(\mu \mathrm{M})$ are the geometric means and are given on the next line. Increase in the $\mathrm{pEC}_{50}$ and decrease in the $\mathrm{EC}_{50}$ reflect enhanced potency of excitant. Time refers to duration after the animals attained the behavioral criterion for kindling. Animals at $1 \mathrm{~d}$ were about 4 months old and animals at $1-2$ months were $5.5-6$ months old.

* $p<0.05, * *<0.01$, compared to implanted controls or unoperated rats of the same age (Newman-Keuls test after one-way ANOVA yielded $p<0.05$ or better).

depolarization increased by about two-thirds (from 230 to 370 $\mathrm{sec}$ ), associated with the virtual disappearance of the afterhyperpolarization (Fig. 1, top). Kindling prevented this developmental change (Fig. 1, bottom). Although depolarizations recorded from slices of the control and unoperated groups were usually smaller than those recorded from slices of the kindled group, these differences in the appearance of the response were observed even when depolarizations were of the same absolute amplitude.

In contrast to their effects on NMDA potency, neither kindling, age, nor $\mathrm{Mg}^{2+}$ significantly altered the responses of CA3 pyramidal cells to AMPA or L-glutamate (Fig. 3, Table 1). These excitants, like NMDA, evoked a rapid depolarization followed by a slow hyperpolarization. Unlike NMDA-induced responses, however, the hyperpolarization did not diminish with age.

Area $C A 1$. In slices from control rats, NMDA was far more potent in depolarizing CA1 than CA3 pyramidal cells (Table 1).
There was little, if any, regional difference in the potency of AMPA, however.

When tested on CAl pyramidal cells 1-2 months after the last evoked seizure, kindling appeared not to have altered the potency of either NMDA (Fig. 4, Table 1) or AMPA (Table 1). In contrast to area $\mathrm{CA} 3$ at this time, responses to these excitants in slices from control as well as kindled rats were characterized by a rapid depolarization followed by a slow hyperpolarization (not shown).

\section{Discussion}

Effect of kindling. These results confirm suggestions from less direct measurements of neuronal depolarization (Morrisett et al., 1989) that kindling enhances the sensitivity of some hippocampal neurons to NMDA. As demonstrated previously, kindling selectively altered responses to NMDA compared with excitatory amino acids active at non-NMDA receptors. [In these 


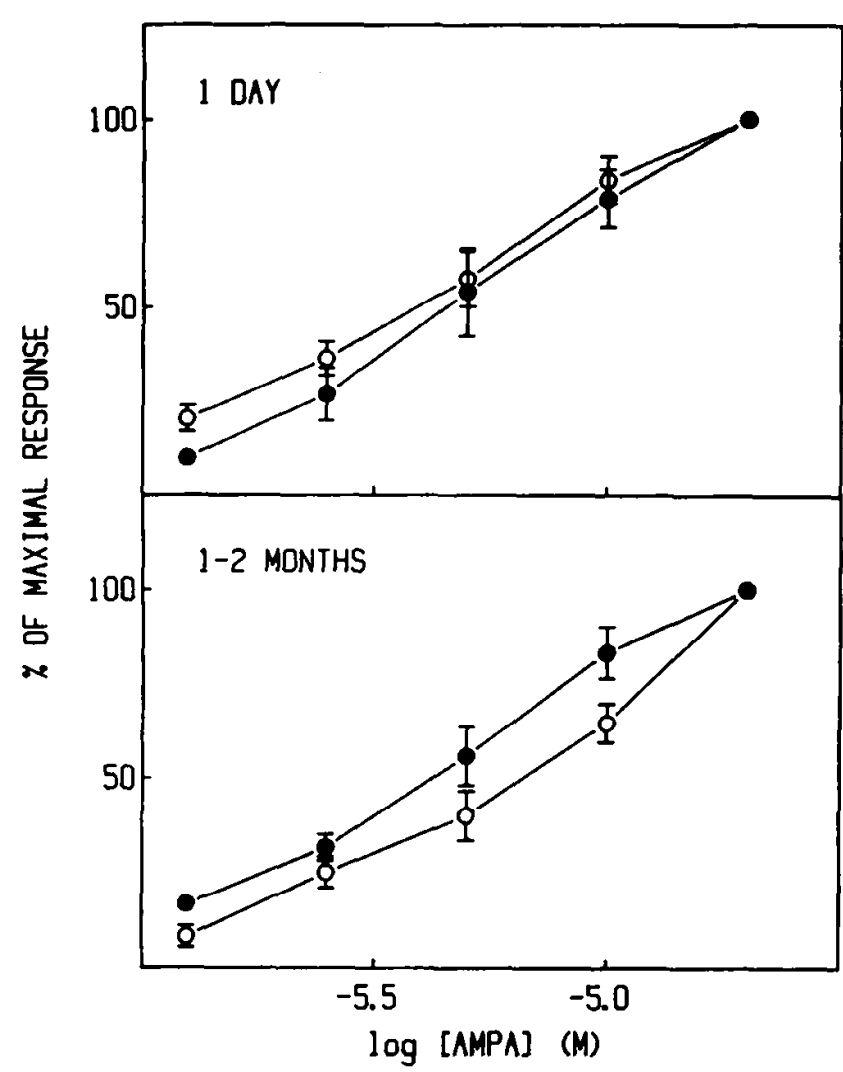

Figure 3. Neither kindling nor age altered the concentration-response curve for AMPA-induced depolarization of $\mathrm{CA} 3$ pyramidal cells. Slices from kindled rats; $O$, slices from electrode-implanted control rats. Recordings were made in the presence of $1 \mathrm{~mm} \mathrm{Mg}^{2+}$. Times refer to interval after the last evoked seizure. Values are means \pm SEM for the number of animals given in Table 1.

grease-gap preparations, responses to glutamate predominantly reflect actions at sites other than the NMDA receptor (Frenguelli et al., 1991; D. Martin and J. V. Nadler, unpublished observations)]. We now show that the effect of kindling is selective for $\mathrm{CA} 3$, as opposed to CA1, pyramidal cells and that it is little affected by removing $\mathrm{Mg}^{2+}$ from the superfusion medium. Thus, not all neuronal populations in the circuit activated by the stimulation respond in the same way. Furthermore, enhanced NMDA agonist potency in area CA3 does not involve a reduced sensitivity to channel block by $\mathrm{Mg}^{2+}$. Kindling-induced changes in NMDA receptor function are in the right direction to underlie maintenance of a hyperexcitable state.

A central issue is whether kindling enhanced NMDA potency in our tests by altering properties of the NMDA receptor or in some other way. A number of factors can influence measures of agonist potency obtained with a grease-gap preparation (Simmonds, 1990; Martin and Nadler, 1991). The most serious technical consideration is the frequent difficulty in obtaining a true maximal response with excitatory amino acids, due to excitotoxic damage, desensitization, and/or incomplete equilibration. Biological variables are many and include the activation or deactivation of voltage-dependent ion conductances secondary to a change in membrane potential, the resistance of receptive cell membranes, and the percentage of extracellular space, as well as modification of the receptor itself. Most of these potential complications are ruled out as a basis for the kindling effect by

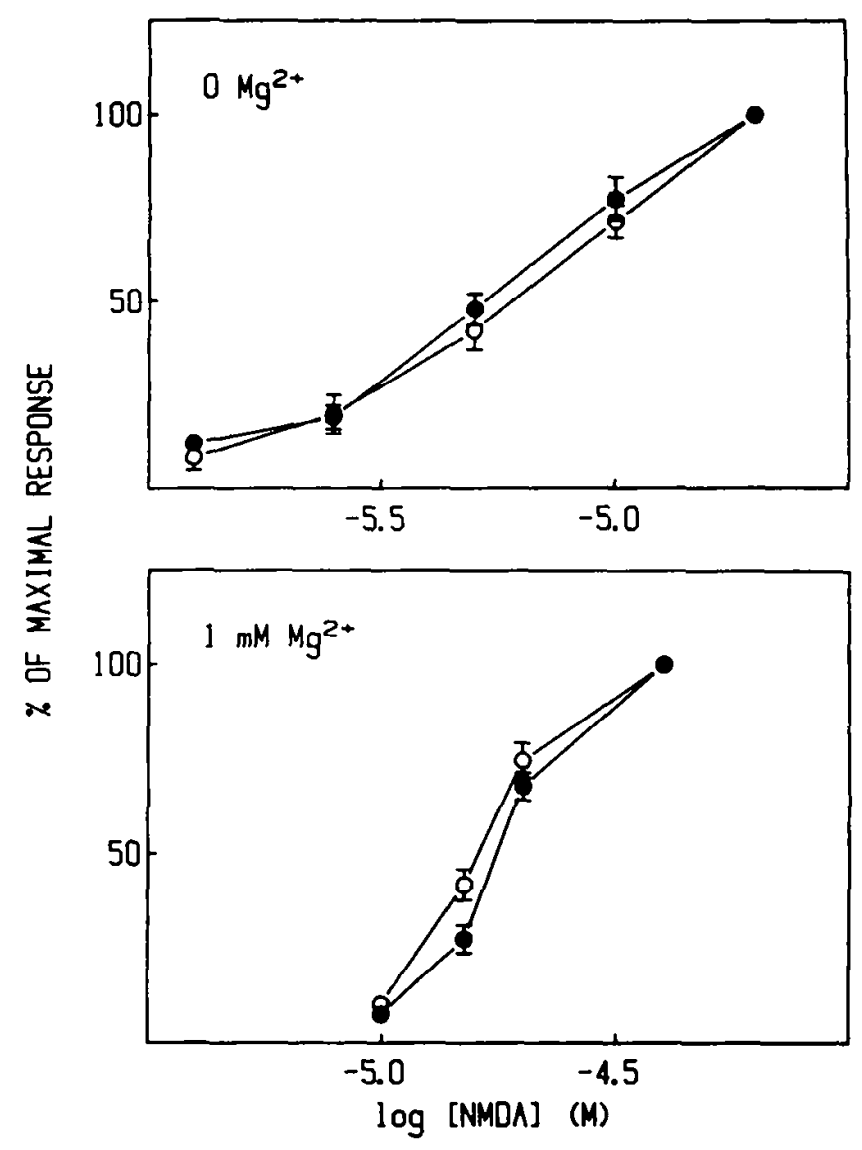

Figure 4. Kindling did not alter the concentration-response curve for NMDA-induced depolarization of CAI pyramidal cells. $\bullet$, Slices from kindled rats; $O$, slices from electrode-implanted control rats. Values are means \pm SEM for the number of animals given in Table 1 .

the specificity of our results with respect to the receptor involved, the hippocampal region, and the time after the last evoked seizure. The enhanced sensitivity of CA 3 pyramidal cells to NMDA after kindling appears to reflect a selective change in the NMDA receptor expressed by those neurons. Although it is well accepted that many forms of neuronal plasticity depend for their induction on activation of the NMDA receptor, initial studies provided no evidence of a role for this receptor in the endurance or permanence of the change. Only recently has it been shown that long-term potentiation can, at least under some conditions, involve a lasting contribution of NMDA receptors to the EPSP (Alonso et al., 1990; Bindman and Murphy, 1990; Bashir et al., 1991). Our results suggest that kindling also not only depends for its induction on NMDA receptor activation, but leads in addition to a modification of receptor properties.

The grease-gap method has proved useful for identifying types of receptor plasticity that involve changes in the potency of amino acid agonists or antagonists. However, this experimental approach by itself can provide only limited information about the cellular and molecular mechanisms that underlie these changes. Membrane binding studies are helpful in this regard. Binding data strongly suggest that kindling enhances NMDA potency, at least in part, by increasing the expression of NMDA receptors. The maximum density of binding sites for NMDA receptor-specific radioligands $-{ }^{3} \mathrm{H}$-glutamate, 3-[(+)-2-(carboxypiperazin-4-yl)]-1,2-3 $\mathrm{H}$-propyl-1-phosphonate ( $\left.{ }^{3} \mathrm{H}-\mathrm{CPP}\right)$, 
tritium-labeled $N$-[(1-thienyl) cyclohexyl] piperidine ( $\left.{ }^{3} \mathrm{H}-\mathrm{TCP}\right)$, and ${ }^{3} \mathrm{H}$-glycine-on rat hippocampal membranes was significantly enhanced 1 month after the last evoked seizure (Yeh et al., 1989; Yeh et al., unpublished observations). Binding data paralleled results of the present grease-gap study with respect to time course; the effect was much greater 1 month after the last evoked seizure than it was immediately after attainment of the behavioral criterion for completion of kindling. Conversely, the lack of kindling-induced change in the potency of AMPA correlated with the absence of effect on the binding of radioligands selective for AMPA or kainate receptors (Okazaki et al., 1990; Vezzani et al., 1990).

An increase in NMDA receptor density would be expected to enhance agonist potency in the presence of a receptor reserve (Kenakin, 1984). If all other factors are constant, changes in agonist potency will be directly proportional to changes in the size of the receptor reserve. At first glance, our results appear inconsistent with this principle, because agonist potency was five- to sixfold greater in kindled rats whereas receptor density was increased by only $40-50 \%$ with most radioligands. However, binding studies were performed with membranes from the whole hippocampus and the potency change was confined to area CA3. It is possible that kindling enhanced NMDA receptor binding to a far greater extent in area CA3 than was evident from studies of whole hippocampal membranes. Our previous receptor autoradiographic study (Okazaki et al., 1989), as well as a similar study by other investigators (Vezzani et al., 1990), failed to show such an enhancement in area CA3 with use of ${ }^{3} \mathrm{H}$-glutamate as the radioligand. However, we have since found that the concentration of ${ }^{3} \mathrm{H}$-glutamate used in that study was too low to reveal a difference between kindled and control animals. The problem is that kindling not only increases the $B_{\max }$ for binding of ${ }^{3} \mathrm{H}$-glutamate to the NMDA receptor, but also reduces the average affinity of the receptor for this and some other ligands (Yeh et al., unpublished observations). Thus, the concentrations of ${ }^{3} \mathrm{H}$-glutamate necessary to demonstrate an effect of kindling are greater than one can use for receptor autoradiography. Recent data further suggest that the additional NMDA receptors expressed in the hippocampus of kindled rats differ from those normally present not only in their ligand affinities, but also in their pharmacological properties (Bonhaus et al., 1991). Another possibility, not yet tested, is that kindling alters the mechanisms by which NMDA receptors are regulated after their insertion into the synaptic membrane (MacDonald et al., 1989; Markram and Segal, 1991).

Increased receptor density would also be expected to reduce the potency of $\mathrm{Mg}^{2+}$ as a blocker of the NMDA receptor channel (Pennefather and Quastel, 1982). No such effect was clearly evident. However, agonist potency may be a more sensitive indicator of changes in receptor density than is $\mathrm{Mg}^{2+}$ antagonism.

Because the effects of kindling on both radioligand binding and agonist potency were much greater at 1 month than at $1 \mathrm{~d}$ after attainment of the behavioral criterion, enhanced NMDA agonist potency in area $\mathrm{CA} 3 \mathrm{might}$ more plausibly play a role in the maintenance than in the initial expression of kindled epilepsy. This change might be expected to unmask normally dormant NMDA receptors on CA3 pyramidal cells and thus to augment and prolong EPSPs (Collingridge et al., 1988). In area CA3, NMDA receptors function mainly at the Schaffer collatcral, commissural, and associational synapses made by CA3 pyramidal cells upon each other (Harris and Cotman, 1986).
Enhancement of transmission at these synapses would overcome inhibitory processes (Stelzer et al., 1987) and potentiate recurrent excitation (Miles and Wong, 1986). Recurrent excitatory connections among CA3 pyramidal cells have been identified as one of the key properties of these cells that facilitates bursting and allows them to initiate limbic seizure activity. Indeed, these neurons exhibit pathologic hyperexcitability after kindling (King et al., 1985). Enhanced NMDA agonist potency might also indirectly modify the actions of neurotransmitters other than excitatory amino acids (Stanton et al., 1987; Stelzer et al., 1987). In these ways, enhanced NMDA agonist potency in a critical region of the hippocampus could maintain a low seizure threshold and perhaps underlie, in part, the spontaneous seizures that can eventually develop in kindled animals (Pinel and Rovner, 1978). Studies of synaptic physiology are needed to evaluate these possibilities. In contrast to its effects on $\mathrm{CA} 3$ pyramidal cells, kindling was reported to enhance the participation of NMDA receptors in transmission onto dentate granule cells from a very early stage in the process, even before the behavioral criterion for completion of kindling was reached (Mody and Heinemann, 1987; Mody et al., 1988). Thus, effects on dentate granule cells could be involved in the establishment of kindling, as well as in its maintenance. It is not clear whether these effects involve the enhanced expression of NMDA receptors or some other mechanism.

Enhancement of NMDA agonist potency could also explain the finding of Jarvie et al. (1990) that kindling increases $\mathrm{K}^{+}$evoked, $\mathrm{Ca}^{2+}$-dependent release of glutamate from slices of hippocampus regio inferior (mainly area CA3), but not from slices of regio superior (area CAl). Under the conditions used in studies of that type, the massive activation of NMDA receptors by released glutamate and aspartate augments the further release of these amino acids from Schaffer collateral-commissural-associational terminals (Martin et al., 1991). Because much of the glutamate release depends on the activation of NMDA receptors, increased receptor density and NMDA agonist potency would be expected to increase this release. Whether kindling enhances glutamate release in response to physiological stimulation remains an open question.

Effect of age. The effects of kindling on NMDA potency were superimposed upon a large and unanticipated reduction with age in the ability of NMDA to depolarize CA3 pyramidal cells. The greatest change was observed between 4 and 5.5-6 months of age. Like the effect of kindling, the effect of age was selective for NMDA compared with excitants that act at non-NMDA receptors. That this was actually an effect of normal development in the rat and not an artifact of electrode implantation or housing in our animal colony was demonstrated by the very similar $\mathrm{EC}_{50}$ values obtained from implanted and unimplanted controls. During the same period, the duration of the depolarizing response increased due to loss of the afterhyperpolarization. In experiments of this type, the afterhyperpolarization has been ascribed to the activation of $\mathrm{Na}^{+} / \mathrm{K}^{+}$-ATPase by the $\mathrm{Na}^{+}$ entry associated with maintained depolarization (Padjen and Smith, 1983; Thompson and Prince, 1986). Kindling probably did not alter this mechanism, because a hyperpolarization continued to follow AMPA-evoked depolarizations. Rather, loss of the NMDA-evoked afterhyperpolarization can probably be explained by a depolarization in each pyramidal cell that was insufficient to activate the $\mathrm{Na}^{+}$pump. This hypothesis does not conflict with the observation that loss of afterhyperpolarization could still be observed even when NMDA-induced depolariza- 
tions in slices from rats of different ages were of the same amplitude, because the amplitude recorded depends not only on the magnitude of depolarization in each pyramidal cell, but also on the number of pyramidal cells that project their axons through the grease barrier and on several technical factors as wcll (Martin and Nadler, 1991). Reduced NMDA potency and loss of the afterhyperpolarization could both be explained by a loss with age of NMDA receptor reserve in CA3 pyramidal cells of the young adult male rat.

This study did not address the effect of age on NMDA potency in area CA 1 . However, a comparison of results we have obtained at ages between 30 and $180 \mathrm{~d}$ revealed no obvious differences in this region. Thus, the effects of age, like those of kindling, may be expressed mainly in area CA3.

The dramatic and selective loss of response to NMDA in area CA3 does not correlate with any other known developmental change in the NMDA receptor. The laminar pattern and density of NMDA receptors develop in the rat hippocampal formation during the first postnatal month or so (Insel et al., 1990; McDonald et al., 1990). Evidence of a declinc in NMDA receptor function during advanced age has been reported (Gonzales et al., 1991). This loss of function may be related to a reduction in strychnine-insensitive glycine binding sites (Miyoshi et al., 1990) and/or glutamate recognition sites (Peterson and Cotman, 1989; Wenk et al., 1991). However, the reduced NMDA potency in area CA3 between 4 and 5.5-6 months of age was not associated with any significant change in the binding of ${ }^{3} \mathrm{H}$-glycine to hippocampal NMDA receptors (Yeh et al., 1989 ) or with any change in the binding of $\mathrm{L}^{3} \mathrm{H}$-glutamate to NMDA receptors in area CA3 (Okazaki et al., 1989). Therefore, our result probably cannot be explained by a loss of NMDA receptors (see also Bonhaus et al., 1990). Alternative mechanisms include changes in sites on the NMDA receptor other than the glycine and glutamate recognition sites, in the signal transduction pathway, in the magnitude of receptor desensitization, in the secondary activation of voltage-sensitive conductances, and in the placement of NMDA receptors on the pyramidal cell. Studies that focus specifically on area CA3 during early adulthood are needed to distinguish among these and other possible mechanisms.

The effect of age on responses of CA3 pyramidal cells to NMDA was completely abolished by kindling. In fact, one could view kindling as a means to prevent the downregulation of responses to NMDA that would otherwise have occurred in the course of normal development. Perhaps by downregulating their NMDA receptor function at some point after these receptors have fulfilled their important roles in neuronal development and differentiation, the CA3 pyramidal cells reduce the probability of limbic seizure discharge. Kindling may lower seizure threshold, in part, by interfering with this process.

\section{References}

Alonso A, de Curtis M, Llinas R (1990) Postsynaptic Hebbian and non-Hebbian long-term potentiation of synaptic efficacy in the entorhinal cortex in slices and in the isolated adult guinea pig brain. Proc Natl Acad Sci USA 87:9280-9284.

Artola A, Bröcher S, Singer W (1990) Different voltage-dependent thresholds for inducing long-term depression and long-term potentiation in slices of rat visual cortex. Nature 347:69-72.

Bashir ZI, Alford S, Davies SN, Randall AD, Collingridge GL (1991) Long-term potentiation of NMDA receptor-mediated synaptic transmission in the hippocampus. Nature 349:156-158.

Baudry M, Evans M, Lynch G (1986) Excitatory amino acids inhibit stimulation of phosphoinositide metabolism by aminergic agonists in hippocampus. Naturc 319:329-331.

Bear MF, Kleinschmidt A, Gu Q, Singer W (1990) Disruption of experience-dependent synaptic modifications in striate cortex by infusion of an NMDA receptor antagonist. J Neurosci 10:909-925.

Bindman LJ, Murphy KPSJ (1990) Delayed onset of potentiation in neocortical epsps during long-term potentiation (LTP) - a postsynaptic mechanism or heterogeneous synaptic inputs? In: Excitatory amino acids and neuronal plasticity (Ben-Ari Y, ed), pp 307-312. New York: Plenum.

Bonhaus DW, Perry WB, McNamara JO (1990) Decreased density, but not number, of $N$-methyl-D-aspartate, glycine and phencyclidine binding sites in hippocampus of senescent rats. Brain Res 532:8286.

Bonhaus DW, Yeh GC, Nadler JV, McNamara JO (1991) NMDA receptor plasticity: selective regulation of receptor subtypes by kindling. Soc Neurosci Abstr 17:75.

Bowe MA, Nadler JV (1990) Developmental increase in the sensitivity to magnesium of NMDA receptors on CAI hippocampal pyramidal cells. Dev Brain Res 56:55-61.

Callaghan DA, Schwark WS (1980) Pharmacological modification of amygdaloid-kindled seizures. Neuropharmacology 19:1131-1136.

Cline HT, Constantine-Paton M (1989) NMDA receptor antagonists disrupt the retinotectal topographic map. Neuron 3:413-426.

Collingridge GL, Kehl SJ, McLennan H (1983) Excitatory amino acids in synaptic transmission in the Schaffer collateral-commissural pathway of the rat hippocampus. J Physiol (Lond) 334:33-46.

Collingridge GL, Herron CE, Lester RAJ (1988) Synaptic activation of $N$-methyl-D-aspartate receptors in the Schaffer collateral-commissural pathway of the rat hippocampus. J Physiol (Lond) 399:283300.

Croucher MJ, Bradford HF, Sunter DC, Watkins JC (1988) Inhibition of the development of electrical kindling of the prepyriform cortex by daily focal injections of excitatory amino acid antagonists. Eur $\mathbf{J}$ Pharmacol 152:29-38.

Fleming WW, Westfall DP, De La Lande IS, Jellett LB (1972) Lognormal distribution of equieffective doses of norepinephrine and acetylcholine in several tissues. J Pharmacol Exp Ther 181:339-345.

Frenguelli BG, Blake JF, Brown MW, Collingridge GL (1991) Electrogenic uptake contributes a major component of the depolarizing action of L-glutamate in rat hippocampal slices. Br J Pharmacol 102: $355-362$

Gaddum JH (1945) Lognormal distributions. Nature 156:463-466.

Glaum SR, Holzwarth JA, Miller RJ (1990) Glutamate receptors activate $\mathrm{Ca}^{2+}$ mobilization and $\mathrm{Ca}^{2+}$ influx into astrocytes. Proc Natl Acad Sci USA 87:3454-3458.

Goddard GV, McIntyre DC, Leech CK (1969) A permanent change in brain function resulting from daily electrical stimulation. Exp Neurol 25:295-330.

Gonzales RA, Brown LM, Jones TW, Trent RD, Westbrook SL, Leslie SW (1991) $N$-methyl-D-aspartate mediated responses decrease with age in Fischer 344 rat brain. Neurobiol Aging 12:219-225.

Gu Q, Bear MF, Singer W (1989) Blockade of NMDA-receptors prevents ocularity changes in kitten visual cortex after reversed monocular deprivation. Dev Brain Res 47:281-288.

Harris EW, Cotman CW (1986) Long-term potentiation of guinea pig mossy fiber responses is not blocked by $N$-methyl-D-aspartate antagonists. Neurosci Lett 70:132-137.

Holmes KH, Bilkey DK, Laverty R, Goddard GV (1990) The $N$-methyl-D-aspartate antagonists aminophosphonovalerate and carboxypiperazinephosphonate retard the development and expression of kindled seizures. Brain Res 506:227-235.

Insel TR, Miller LP, Gelhard RE (1990) The ontogeny of excitatory amino acid receptors in rat forebrain. I. $N$-methyl-D-aspartate and quisqualate receptors. Neuroscience $35: 31-43$.

Jarvie PA, Logan TC, Geula C, Slevin JT (1990) Entorhinal kindling permanently enhances $\mathrm{Ca}^{2+}$-dependent $\mathrm{L}$-glutamate release in regio inferior of rat hippocampus. Brain Res 508:188-193.

Kenakin TP (1984) The classification of drugs and drug receptors in isolated tissues. Pharmacol Rev 36:165-222.

King GL, Dingledine R, Giacchino JL, McNamara JO (1985) Abnormal neuronal excitability in hippocampal slices from kindled rats. J Neurophysiol 54:1295-1304.

Kleinschmidt A, Bear MF, Singer W (1987) Blockade of "NMDA" receptors disrupts experience-dependent modifications of kitten striate cortex. Science 238:355-358. 
Lindgren S, Simmonds MA (1987) Adaptation of the GABA -receptor complex in rat brain during chronic elevation of $\mathrm{GABA}$ by ethanolamine $O$-sulphate. Br J Pharmacol 91:617-625.

Löscher W, Hönack D (1991) Anticonvulsant and behavioral effects of two novel competitive $N$-methyl-D-aspartic acid receptor antagonists, CGP 37849 and CGP 39551, in the kindling model of epilepsy. Comparison with MK-80I and carbamazepine. J Pharmacol Exp Ther 256:432-440.

MacDonald JF, Mody I, Salter MW (1989) Regulation of $N$-mcthylD-aspartate receptors revealed by intracellular dialysis of murine neurones in culture. J Physiol (Lond) 414:17-34.

Marek P, Ben-Eliyahu S, Gold M, Liebeskind JC (1991) Excitatory amino acid antagonists (kynurenic acid and MK-801) attenuate the development of morphine tolerance in the rat. Brain Res 547:77-81,

Markram H, Segal M (1991) Calcimycin potentiates responses of rat hippocampal pyramidal cells to $N$-methyl-D-aspartatc. Brain Res 540: 322-324.

Martin D, Nadler JV (1991) Grease-gap methods for studying pharmacology of excitatory amino acids on central nervous system neurons. In: Methods in neuroscience, Vol 4 (Conn PM, ed), pp 349364. San Diego: Academic.

Martin D, Bowe MA, Nadler JV (1989) A grease-gap method for studying the excitatory amino acid pharmacology of CAl hippocampal pyramidal cells. J Neurosci Methods 29:107-114.

Martin D, Nadler JV, McNamara JO (1990) Kindling enhances sensitivity of CA3 hippocampal pyramidal cells to NMDA. Soc Neurosci Abstr 16:307.

Martin D, Bustos GA, Bowe MA, Bray SD, Nadler JV (1991) Autoreceptor regulation of glutamate and aspartate release from slices of the hippocampal CAI area. J Neurochem 56:1647-1655.

McDonald JW, Johnston MV, Young AB (1990) Differential ontogenic development of three receptors comprising the NMDA receptor/channel complex in the rat hippocampus. Exp Neurol 110:237247.

McNamara JO, Bonhaus DW, Shin C, Crain BJ, Gellman RL, Giacchino JL (1985) The kindling model of epilepsy: a critical review. Crit Rev Clin Neurobiol 1:341-391.

McNamara JO, Russell RD, Rigsbee L, Bonhaus DW (1988) Anticonvulsant and antiepileptogenic actions of MK-801 in the kindling and electroshock models. Neuropharmacology 27:563-568.

Miles R, Wong RKS (1986) Excitatory synaptic interactions between CA3 neurons in the guinea-pig hippocampus. J Physiol (Lond) 373: $397-418$.

Miyoshi R, Kito S, Doudou N, Nomoto T (1990) Age-related changes of strychnine-insensitive glycine receptors in rat brain studied by in vitro autoradiography. Synapse 6:338-343.

Mody I, Heinemann U (1987) NMDA receptors of dentate gyrus granule cells participate in synaptic transmission following kindling. Nature 326:701-704.

Mody I, Stanton PK, Heinemann U (1988) Activation of $N$-methylD-aspartate receptors parallels changes in cellular and synaptic properties of dentate gyrus granule cells after kindling. J Neurophysiol 59: 1033-1054.

Morrisett RA, Chow C, Nadler JV, McNamara JO (1989) Biochemical evidence for enhanced sensitivity to $N$-methyl-D-aspartate in the hippocampal formation of kindled rats. Brain Res 496:25-28.

Morrisett RA, Chow CC, Sakaguchi T, Shin C, McNamara JO (1990) Inhibition of muscarinic-coupled phosphoinositide hydrolysis by $N$-methyl-D-aspartate is dependent on depolarization via channel activation. J Neurochem 54:1517-1525.

Nadler JV, Martin D, Bowe MA, Morrisett RA, McNamara JO (1990) Kindling, prenatal exposure to ethanol and postnatal development selectively alter responses of hippocampal pyramidal cells to NMDA. In: Excitatory amino acids and neuronal plasticity (Ben-Ari $Y$, ed), pp 407-417. New York: Plenum.

Okazaki MM, McNamara JO, Nadler JV (1989) $N$-methyl-D-aspartate receptor autoradiography in rat brain after angular bundle kindling. Brain Res 482:359-364.

Okazaki MM, McNamara JO, Nadler JV (1990) Kainate and quisqualate receptor autoradiography in rat brain after angular bundle kindling. Neuroscience 37:135-142.

Padjen AL, Smith PA (1983) The rolc of the electrogenic sodium pump in the glutamate afterhyperpolarization of frog spinal cord. J Physiol (Lond) 336:433-451.

Pennefather P, Quastel DMJ (1982) Modification of dose-response curves by effector blockade and uncompetitive antagonism. Mol Pharmacol 22:369-380.

Peterson C, Cotman CW (1989) Strain-dependent decrease in glutamate binding to the $N$-methyl-D-aspartic acid receptor during aging. Neurosci Lett 104:309-313.

Peterson DW, Collins JF, Bradford HF (1983) The kindled amygdala model of epilepsy: anticonvulsant action of amino acid antagonists. Brain Res 275:169-172.

Pinel JP, Rovner LI (1978) Electrode placement and kindling-induced experimental epilepsy. Exp Neurol 58:335-346.

Racine RJ (1972) Modification of seizure activity by electrical stimulation. II. Motor seizure. Electroencephalogr Clin Neurophysiol 32: 281-294.

Simmonds MA (1990) Use of slices for quantitative pharmacology. In: Preparations of vertebrate central nervous system in vitro (Jahnsen H, ed), pp 49-76. Chichester: Wiley.

Stanton PK, Jones RSG, Mody I, Heinemann U (1987) Epileptiform activity induced by lowering extracellular $\left[\mathrm{Mg}^{2+}\right]$ in combined hippocampal-entorhinal cortex slices: modulation by receptors for norepinephrine and $N$-methyl-D-aspartate. Epilepsy Res 1:53-62.

Stelzer A, Slater NT, ten Bruggencate G (1987) Activation of NMDA receptors blocks GABAergic inhibition in an in vitro model of epilepsy. Nature 326:698-701.

Tallarida RJ, Murray RB (1987) Manual of pharmacological calculations with computer programs, 2d ed. New York: Springer.

Thompson SM, Prince DA (1986) Activation of electrogenic sodium pump in hippocampal CAI neurons following glutamate-induced depolarization. J Neurophysiol 56:507-522.

Trujillo KA, Akil H (1991) Inhibition of morphine tolerance and dependence by the NMDA receptor antagonist MK-801. Science 251: 85-87.

Usowicz MM, Gallo V, Cull-Candy SG (1989) Multiple conductance channels in type- 2 cerebellar astrocytes activated by excitatory amino acids. Nature 339:380-383.

Vezzani A, Serafini R, Samanin R, Foster AC (1990) Autoradiographical analysis of excitatory amino acid binding sites in rat hippocampus during the development of hippocampal kindling. Brain Res 526:113121.

Wenk GL, Walker IC, Price DL, Cork LC (1991) Loss of NMDA, but not GABA-A, binding in the brains of aged rats and monkeys. Neurobiol Aging 12:93-98.

Williams TL, Smith DAS, Burton NR, Stone TW (1988) Amino acid pharmacology in neocortical slices: evidence for bimolecular actions from an extension of the Hill and Gaddum-Schild equations. $\mathrm{Br} J$ Pharmacol 95:805-810.

Yeh G-C, Bonhaus DW, Nadler JV, McNamara JO (1989) $N$-methylD-aspartate receptor plasticity in kindling: quantitative and qualitative alterations in the $N$-methyl-D-aspartate receptor-channel complex. Proc Natl Acad Sci USA 86:8157-8160. 